Article

\title{
Catalytic Ozonation of Toluene Using Chilean Natural Zeolite: The Key Role of Bronsted and Lewis Acid Sites
}

\author{
Serguei Alejandro-Martín ${ }^{1, *(\mathbb{B})}$, Héctor Valdés ${ }^{2, *(\mathbb{D})}$, Marie-Hélène Manero ${ }^{3}$ \\ and Claudio A. Zaror ${ }^{4}$ \\ 1 Nanomaterials and Catalysts for Sustainable Processes (NanoCatpPS), Wood Engineering Department, \\ Faculty of Engineering, Universidad del Bío-Bío (UBB), 4030000 Concepción, Chile \\ 2 Laboratorio de Tecnologías Limpias, Facultad de Ingeniería, Universidad Católica de la Santísima \\ Concepción, 4030000 Concepción, Chile \\ 3 Laboratoire de Génie Chimique, Université de Toulouse, CNRS, INPT, UPS, F-31030 Toulouse, France; \\ marie-helene.manero@iut-tlse3.fr \\ 4 Departamento de Ingeniería Química, Facultad de Ingeniería, Universidad de Concepción, \\ 4030000 Concepción, Chile; czaror@udec.cl \\ * Correspondence: salejandro@ubiobio.cl (S.A.); hvaldes@ucsc.cl (H.V.); \\ Tel.: +56-41-3111168 (S.A.); +56-41-2345044 (H.V.)
}

Received: 3 April 2018; Accepted: 2 May 2018; Published: 17 May 2018

\begin{abstract}
The influence of surface physical-chemical characteristics of Chilean natural zeolite on the catalytic ozonation of toluene is presented in this article. Surface characteristics of natural zeolite were modified by acid treatment with hydrochloric acid and ion-exchange with ammonium sulphate. Prior to catalytic ozonation assays, natural and chemically modified zeolite samples were thermally treated at 623 and $823 \mathrm{~K}$ in order to enhance Brønsted and Lewis acid sites formation, respectively. Natural and modified zeolite samples were characterised by $\mathrm{N}_{2}$ adsorption at $77 \mathrm{~K}$, elemental analysis, X-ray fluorescence, and Fourier transform infrared (FTIR) spectroscopy, using pyridine as a probe molecule. The highest values of the reaction rate of toluene oxidation were observed when NH4Z1 and 2NH4Z1 zeolite samples were used. Those samples registered the highest density values of Lewis acid sites compared to other samples used here. Results indicate that the presence of strong Lewis acid sites at the $2 \mathrm{NH} 4 \mathrm{Z} 1$ zeolite surface causes an increase in the reaction rate of toluene oxidation, confirming the role of Lewis acid sites during the catalytic ozonation of toluene at room temperature. Lewis acid sites decompose gaseous ozone into atomic oxygen, which reacts with the adsorbed toluene at Brønsted acid sites. On the other hand, no significant contribution of Brønsted acid sites on the reaction rate was registered when NH4Z1 and 2NH4Z1 zeolite samples were used.
\end{abstract}

Keywords: Brønsted acid sites; catalytic ozonation; Chilean natural zeolite; Lewis acid sites; toluene

\section{Introduction}

The growing concern to protect ambient air quality and public health has led to the development of new air pollution control techniques. Among of them, catalytic ozonation has emerged as a novel technology with a great potential to be used in the oxidation of toxic volatile organic compounds (VOCs). In this new process, different microporous materials have been applied. Activated carbons have been the most common used material for VOCs elimination [1-4]. However, its low ignition point and low chemical stability in the presence of gaseous ozone has limited its application at the industrial scale [5]. Thus, synthetic zeolites have come to the attention of researchers due to their good adsorptive capacity, catalytic activity and thermal stability [6]. Synthetic zeolites have been 
used to eliminate low concentrations of VOCs (butan-2-one and toluene) from contaminated streams, using a combined procedure (adsorption and ozonation) as alternative treatment. Regeneration of VOC-saturated zeolites was conducted by ozonation in order to achieve a complete mineralization of adsorbed organic compounds [7,8]. The use of magnesium-exchanged zeolites (Mn-Y, Mn-MOR, and Mn-ZSM-5) has been reported in the catalytic ozonation of benzene. The Mn-Y zeolite simple showed the higher activity and selectivity to $\mathrm{CO}_{2}$ and a linear relationship was observed between benzene and ozone consumption [9].

In the same way, synthetic zeolites and mesoporous materials have been applied in the catalytic ozonation of toluene. Toluene was removed via adsorption (50\%) and ozonation (20-40\%), which was catalytically enhanced by the presence of Lewis acid sites [10]. Chao et al. investigated the performance of a combined ozone-zeolite (13X) system to eliminate gaseous toluene at indoor environments. The degradation of toluene seemed to be contributed by active oxygen atoms, generated from the decomposition of molecular ozone at Lewis acid sites of zeolite framework [11]. Furthermore, catalytic ozonation of toluene was conducted over $\mathrm{NaX}, \mathrm{NaY}$ and MCM-41 for indoor air purification purposes, taking advantage of the strong oxidizing capability of atomic oxygen generated from adsorbed ozone at Lewis acid sites [12]. Thus, most of the researchers had pointed out the advantages of catalytic ozonation of VOCs using synthetic zeolites, considering the positive contribution of Lewis acid sites.

Likewise, natural zeolites have recently been employed for air pollution control [13,14], mainly motivated by their low cost, high availability, and the presence of active acid sites [15]. Such studies have focused on the removal of sulphur dioxide from combustion gases [16], the removal of VOCs (via adsorption) [17,18], the regeneration of toluene-saturated natural zeolites (via ozonation) [19], and the catalytic oxidation of toluene [20,21]. Among natural zeolites, clinoptilolite is the most common material used for toluene oxidation. In particular, this article aims to study the influence of the surface physical-chemical characteristics of natural and modified Chilean zeolite samples during the catalytic ozonation of toluene at room temperature.

\section{Results and Discussion}

\subsection{Physical-Chemical Characteristics of Natural and Modified Zeolites}

Natural and modified zeolite samples were characterised by nitrogen adsorption at $77 \mathrm{~K}$, and the results are shown in Table 1. Nitrogen adsorption isotherms revealed a combination of type I and type IV characteristic isotherms, according to the International Union of Pure and Applied Chemistry (IUPAC) classification [22], with a rapid filling of micropores at low relative pressure $\left(P / P_{0}\right)$ values. In the same way, an increase of the adsorbed nitrogen was observed for values of $P / P_{0}$ close to 1 , possibly due to the presence of mesopores. Results obtained here are in accordance with those reported elsewhere [23,24].

Table 1. Characterisation of zeolite samples.

\begin{tabular}{|c|c|c|c|c|c|c|c|c|c|c|}
\hline \multirow{3}{*}{ Samples } & \multirow{3}{*}{$\mathrm{S}_{623}\left(\mathrm{~m}^{2} \cdot \mathrm{g}^{-1}\right)$} & \multirow{3}{*}{$\mathrm{Na}_{2} \mathrm{O}(\%)^{\mathrm{a}}$} & \multirow{3}{*}{$\mathrm{CaO}(\%)^{\mathrm{a}}$} & \multirow{3}{*}{$\mathrm{K}_{2} \mathrm{O}(\%)^{\mathrm{a}}$} & \multirow{3}{*}{$\operatorname{MgO}(\%)^{a}$} & \multirow{3}{*}{ Si/Al Ratio } & \multicolumn{4}{|c|}{ Acid Sites Concentration $\left(\mu \mathrm{mol} \cdot \mathrm{g}^{-1}\right)^{b}$} \\
\hline & & & & & & & \multicolumn{2}{|c|}{$623 \mathrm{~K}$} & \multicolumn{2}{|c|}{$773 \mathrm{~K}$} \\
\hline & & & & & & & Bronsted & Lewis & Brønsted & Lewis \\
\hline NZ & 205 & 1.89 & 4.57 & 0.74 & 0.66 & 5.34 & 0.4 & 31.1 & 1.4 & 42.8 \\
\hline $\mathrm{ZH} 2.4$ & 434 & 0.43 & 1.48 & 0.64 & 0.39 & 7.1 & 64.6 & 72.0 & 92.9 & 70.3 \\
\hline NH4Z1 & 181 & 0.68 & 2.36 & 0.67 & 0.46 & 5.32 & 281.2 & 60.5 & 189.0 & 165.0 \\
\hline 2NH4Z1 & 171 & 0.26 & 1.82 & 0.39 & 0.37 & 5.34 & 274.5 & 201.9 & 179.8 & 282.8 \\
\hline
\end{tabular}

X-ray powder diffraction (XRD) patterns of natural and modified zeolite samples have been previously reported $[25,26]$. XRD patterns indicate that chemical modification treatments of natural zeolite do not cause any significant changes in the zeolite framework.

A significant increase in the value of the surface area of the $\mathrm{ZH} 2.4$ zeolite sample was registered after the acid treatment of natural zeolite, which was connected to the observed decrease of $17.3 \%$ 
in the aluminium content. Aluminium is released in its soluble form from the zeolite framework through a de-cationisation and dealumination process $[27,28]$, which is also responsible for the increase of $\mathrm{Si} / \mathrm{Al}$ ratio. In the case of $\mathrm{NH} 4 \mathrm{Z1}$ and $2 \mathrm{NH} 4 \mathrm{Z1}$ samples, generated after the ion-exchange of natural zeolite with a solution of ammonium sulphate, a slight reduction in the value of surface area without significant changes in the $\mathrm{Si} / \mathrm{Al}$ ratio was observed. Moreover, an important reduction in the content of compensating cations of those samples was registered by the XRF analysis. For the $2 \mathrm{NH} 4 \mathrm{Z1}$ zeolite sample, results showed a decrease of $86.2 \%, 60.2 \%, 47.3 \%$, and $43.9 \%$ of $\mathrm{Na}_{2} \mathrm{O}, \mathrm{CaO}$, $\mathrm{K}_{2} \mathrm{O}$, and $\mathrm{MgO}$, respectively. Such high removal efficiencies were achieved when two sequences ammonium ion-exchange were applied, showing the high effectiveness of this method in the reduction of compensating cations. The reduction in the content of compensating cations has been related to the accessibility of ozone and toluene to active surface sites of the zeolite framework, leading to an increase in the oxidation rate of VOCs [26,29].

The values of Brønsted and Lewis acid site contents of natural and modified zeolite samples thermally treated at 623 and $773 \mathrm{~K}$ are listed in Table 1; they were obtained by Py-FTIR analysis. Figure 1 displays the strength of such acidic sites after the thermal desorption of pyridine at different temperatures. As it can be seen, natural (NZ) and ammonium-modified zeolite samples (NH4Z1 and 2NH4Z1), previously out-gassed at $623 \mathrm{~K}$, showed a high content of Brønsted acid sites as compared to the same samples out-gassed at $773 \mathrm{~K}$. In the case of zeolite samples (ZN, NH4Z1, and 2NH4Z1) out-gassed at $773 \mathrm{~K}$, higher numbers of Lewis acid sites were observed.

Thus, the results obtained here show a general trend in the content of Brønsted and Lewis acid sites of natural and modified zeolite samples, as follows:

- Amount of Brønsted acid sites in zeolite samples out-gassed at $623 \mathrm{~K}$ :

$$
\mathrm{NH} 4 \mathrm{Z1}>2 \mathrm{NH} 4 \mathrm{Z1}>\mathrm{ZH} 2.4>\mathrm{ZN}
$$

- Amount of Lewis acid sites in zeolite samples out-gassed at $773 \mathrm{~K}$ :

$$
2 \mathrm{NH} 4 \mathrm{Z1}>\mathrm{NH} 4 \mathrm{Z1}>\mathrm{ZH} 2.4>\mathrm{ZN}
$$

NH4Z1 and 2NH4Z1 zeolite samples (out-gassed at $623 \mathrm{~K}$ ) registered the highest amounts of Brønsted acid sites among all of the samples studied here. This can be attributed to the generation of new Brønsted acid sites as a result of the ammonia release during the thermal treatment at $623 \mathrm{~K}$. The thermal evolution of ammonia took place from ammonium ions $\left(\mathrm{NH}_{4}{ }^{+}\right)$that were previously incorporated in the zeolite framework by ion-exchange. In the same way, the amount of Brønsted acid sites generated by the applied chemical and thermal treatments favoured the generation of new Lewis acid sites during the out-gassing procedure conducted at $823 \mathrm{~K}$. Brønsted acid site transformation into Lewis acid sites have been reported before [30].

Comparing the results for the out-gassed zeolite samples at $623 \mathrm{~K}$, it was found that the amount of Brønsted sites incorporated in the ZH2.4 sample as result of the acid modification method [28] was lower than the amount of Brønsted acid sites incorporated in the NH4Z1 and 2NH4Z1 samples modified by ammonium ion-exchange. The higher amount of Brønsted acid sites in NH4Z1 and 2NH4Z1 zeolite samples could be attributed to the generation of new Brønsted acid sites coming from the incorporation of ammonium ions during the ion-exchange, as previously reported [31].

As can be seen in Figure 1, a high amount of Brønsted acid sites were registered when adsorbed pyridine molecules were desorbed at temperatures between 723 and $773 \mathrm{~K}$, for NH4Z1 and 2NH4Z1 samples. This can be attributed to Brønsted acid sites of higher strength, as a consequence of the applied chemical and thermal treatment. 

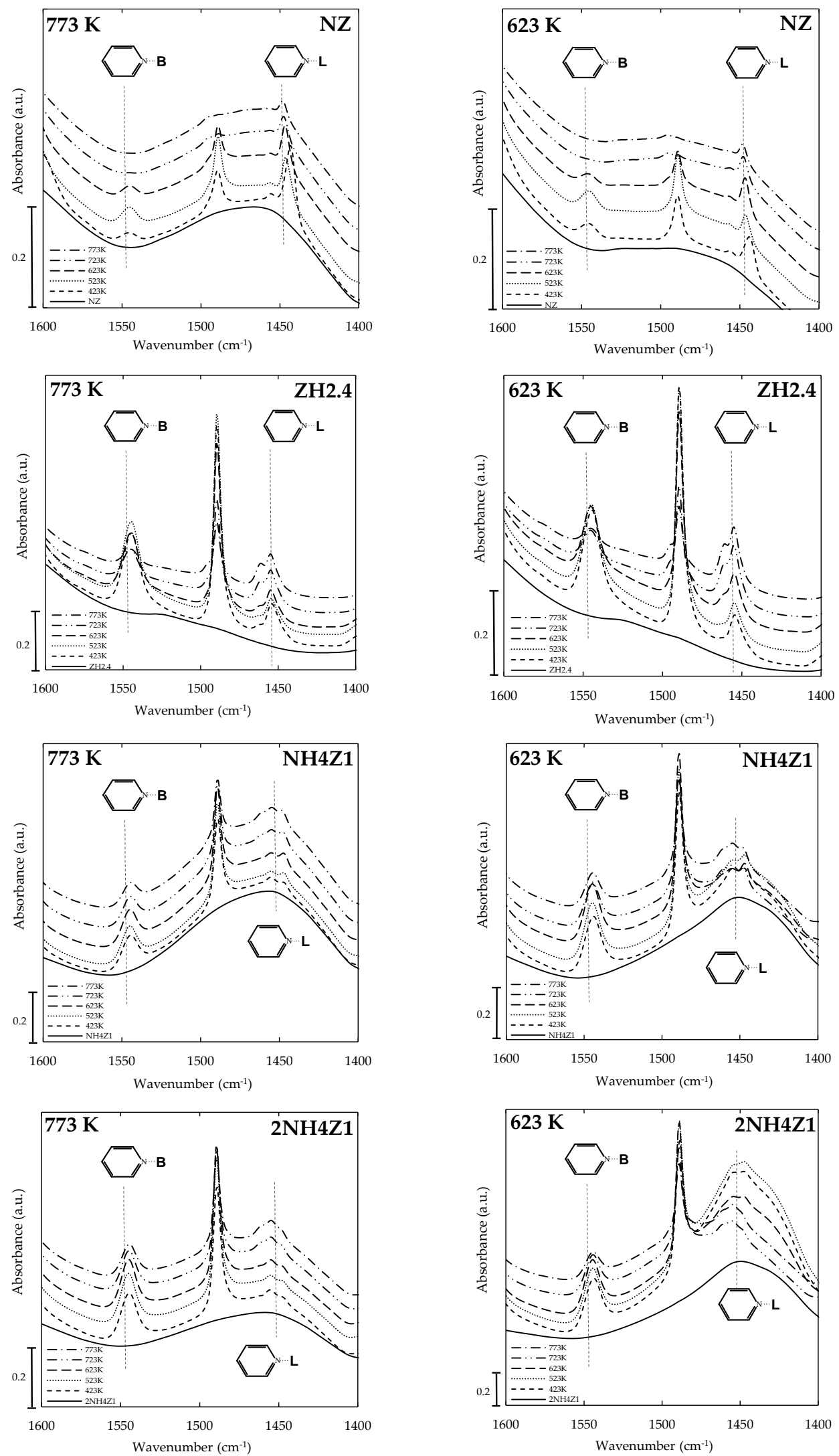

Figure 1. FTIR spectra of pyridine-saturated natural and modified zeolite samples. 
In the case of the out-gassed zeolite samples at $773 \mathrm{~K}$, a considerable increase of Lewis acid sites was observed in comparison to the number of Lewis sites registered in the samples out-gassed at $623 \mathrm{~K}$, in equal conditions. In addition, an interesting behaviour was observed for NH4Z1 and 2NH4Z1 samples, where the concentration of Lewis acid sites increased as the temperature rose. However, the concentration of Lewis sites at the surface of $\mathrm{ZN}$ and $\mathrm{ZH} 2.4$ samples fell as the temperature increased, indicating the presence of Lewis acid sites of lower strength. Py-FTIR analyses confirmed the higher strength of Lewis acid sites obtained from the thermal transformation of Brønsted sites previously formed by ion-exchange, in comparison to those Lewis acid sites generated from the thermal treatment of Brønsted acid sites incorporated into natural zeolite during the acid treatment stage.

\subsection{Catalytic Ozonation Using Natural and Modified Zeolites at $293 \mathrm{~K}$}

The contribution of physical-chemical characteristics of natural zeolite on the catalytic ozonation of toluene was analysed in this study using natural and modified natural zeolite samples (ZN, ZH2.4, NH4Z1, and 2NH4Z1) out-gassed at 623 and $823 \mathrm{~K}$. Catalytic ozonation experiments were conducted using a differential plug flow reactor (PFR), as described in the next section. All experiments were conducted in the absence of mass transfer limitations. Working conditions were experimentally set by applying the Madon-Boudart criterion [32]. Preliminary experiments were conducted at different flow rates in the range from 50 to $150 \mathrm{~cm}^{3} \cdot \mathrm{min}^{-1}$ (at constant space time) and no variations in toluene conversion were registered, indicating the absence of external mass transfer limitations. Moreover, the absence of internal mass transfer limitations was assessed using $150 \mathrm{mg}$ of zeolite samples of different particle sizes in the range from 0.2 to $0.6 \mathrm{~mm}$ at an inlet flow of $100 \mathrm{~cm}^{3} \cdot \mathrm{min}^{-1}$. Experimental results showed a constant conversion value of toluene for this range of particle sizes. Thus, the following experiments were performed at $101 \mathrm{kPa}, 293 \mathrm{~K}$, using an inlet flow of $100 \mathrm{~cm}^{3} \cdot \mathrm{min}^{-1}, C_{\text {Tin }}=42.3 \mu \mathrm{mol} \cdot \mathrm{cm}^{-3} ; C_{\text {O3in }}=3.57 \mu \mathrm{mol} \cdot \mathrm{dm}^{-3}$, with an average particle size of $0.36 \mathrm{~mm}$, where the external and internal mass transfer effects were found to be insignificant. Zeolite samples were mixed with particles of quartz of the same particle size with a mass ratio 1:4 in order to obtain about $10 \%$ toluene conversion. The reaction rate of toluene catalytic oxidation with ozone in the presence of zeolite was calculated using toluene conversion at different experimental conditions, applying the PFR design equation given by Equation (1).

$$
-r_{T o l}=\frac{F}{W} X_{T o l}
$$

Figure 2 illustrates the variation of the reaction rates of the catalytic ozonation of toluene as a function of zeolite samples with different chemical surface compositions.

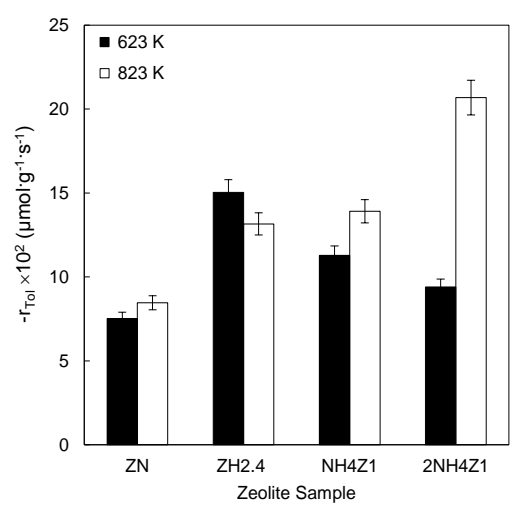

Figure 2. Effect of the physical-chemical characteristics of natural and modified zeolites on the toluene ozonation reaction rate. Experimental conditions were as follows: $m_{\text {sample }}=150 \mathrm{mg} ; 101 \mathrm{kPa}, 293 \mathrm{~K}$; $C_{\text {Tin }}=42.3 \mu \mathrm{mol} \cdot \mathrm{cm}^{-3} ; C_{\text {O3in }}=3.57 \mu \mathrm{mol} \cdot \mathrm{dm}^{-3}$. 
As can be seen, the highest reaction rate $\left(0.15 \mu \mathrm{mol} \cdot \mathrm{g}^{-1} \cdot \mathrm{s}^{-1}\right)$ for the out-gassed samples at $623 \mathrm{~K}$ was registered for the $\mathrm{ZH} 2.4$ zeolite sample. Among the zeolite samples out-gassed at $823 \mathrm{~K}$, the highest reaction rate $\left(0.21 \mu \mathrm{mol} \cdot \mathrm{g}^{-1} \cdot \mathrm{s}^{-1}\right)$ was achieved by the $2 \mathrm{NH} 4 \mathrm{Z1}$ zeolite sample. It is clear that reaction rates for natural and ammonium modified zeolite samples (previously out-gassed at $823 \mathrm{~K}$ ) are higher than the reaction rate registered for the same out-gassed samples at $623 \mathrm{~K}$.

An opposite tendency was observed for the ZH2.4 zeolite sample. The higher reaction rate was reached by the out-gassed samples at $623 \mathrm{~K}$. This tendency could be associated to the higher density of Lewis acid sites on the ZH2.4 sample out-gassed at $623 \mathrm{~K}$. In the same way, a higher density of Lewis acid sites on NZ, NH4Z1, and 2NH4Z1 samples could be responsible for the higher reaction rate obtained when zeolite samples out-gassed at $827 \mathrm{~K}$ were used. These results suggest that the density of Lewis acid sites plays an important role in the catalytic ozonation of toluene at room temperature.

Thus, the highest reaction rate was attained when the $2 \mathrm{NH} 4 \mathrm{Z} 1$ sample out-gassed at $823 \mathrm{~K}$ was used. Such a result could be related to the highest density of Lewis acid sites $\left(282.8 \mu \mathrm{mol} \cdot \mathrm{g}^{-1}\right)$ of this sample after thermal treatment. Several studies have reported the role of Lewis acid sites on the generation of active atomic oxygen species. Such species could react with adsorbed toluene on the surface of zeolite samples, as represented by Equation (2) [33-37].

$$
\mathrm{C}_{7} \mathrm{H}_{8}+18 \mathrm{O}^{\bullet} \rightarrow 7 \mathrm{CO}_{2}+4 \mathrm{H}_{2} \mathrm{O}
$$

Figure 3 shows the influence of the density of strong Lewis acid sites on the reaction rate of toluene ozonation using natural and modified zeolite as catalysts.

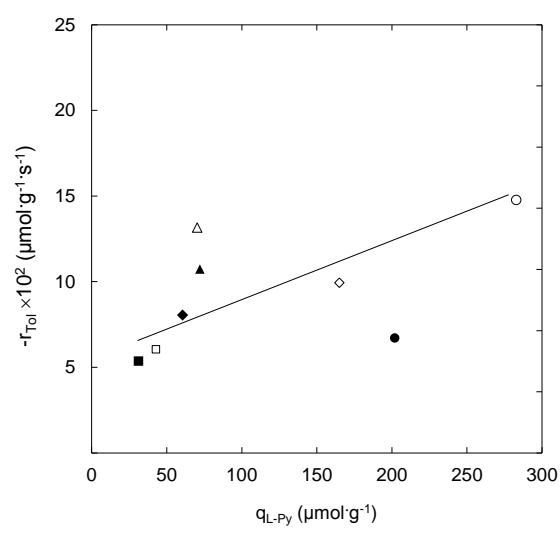

Figure 3. Influence of strong Lewis acid sites on the catalytic ozonation reaction rate. Filled markers represent zeolite samples out-gassed at $623 \mathrm{~K}$ and open markers stand for samples out-gassed at $823 \mathrm{~K}$ : $(\boldsymbol{\square} / \square) \mathrm{NZ} ;(\boldsymbol{\Delta} / \Delta) \mathrm{ZH} 2.4 ;(\diamond / \diamond) \mathrm{NH} 4 \mathrm{Z1} ;(\bullet / \bigcirc)$ 2NH4Z1. Experimental conditions were as follows: $m_{\text {sample }}=150 \mathrm{mg} ; 101 \mathrm{kPa}, 293 \mathrm{~K} ; C_{\text {Tin }}=42.3 \mu \mathrm{mol} \cdot \mathrm{cm}^{-3} ; C_{\text {O3in }}=3.57 \mu \mathrm{mol} \cdot \mathrm{dm}^{-3}$.

A trend denoted by a straight line in Figure 3 could represent a direct relation between the presence of strong Lewis acid sites and the increase in the toluene ozonation reaction rate for the out-gassed natural and modified zeolite samples. The higher density of strong Lewis acid sites on natural and ammonium-modified zeolite samples seems to favour the reaction between adsorbed toluene at Brønsted acid sites and active atomic oxygen generated from the ozone interaction with strong Lewis acid sites. However, the case of the 2NH4Z1 sample (out-gassed at $623 \mathrm{~K}$ ) did not follow this trend. This behaviour can be associated to a higher number of Brønsted acid sites on this sample. As Py-FTIR analyses showed, the highest density of Brønsted acid sites $\left(274.5 \mu \mathrm{mol} \cdot \mathrm{g}^{-1}\right)$ was obtained for this sample after chemical and thermal treatment. The affinity of toluene molecules towards Brønsted acid sites has been previously reported [38,39]. This behaviour could negatively affect the reaction progress (see Figure 4) due to the strong adsorption of toluene at Brønsted acid sites 
of the 2NH4Z1 sample (out-gassed at $623 \mathrm{~K}$ ). In addition, this sample registers the highest adsorption capacity among all of the samples studied, as it indicated elsewhere [25].

A minor deviation from the straight line was registered for the ZH2.4 $623 \mathrm{~K}$ sample, as shown in Figure 3. The lower interaction of active Lewis acid sites on the ZH2.4 sample towards ozone has also been previously reported [29]. The decrease in ozone decomposition produces less active atomic oxygen species, leading to the observed decrease in the reaction rate of toluene catalytic oxidation (see Figure 3).

On the other hand, the highest reaction rate value was registered for the 2NH4Z1 $823 \mathrm{~K}$ sample, with the highest density of strong Lewis acid sites $\left(282.8 \mu \mathrm{mol} \cdot \mathrm{g}^{-1}\right)$. These strong sites enhance gaseous ozone decomposition, generating active atomic oxygen $\left(\mathrm{O}^{\bullet}\right)$, as previously reported $[26,29,40,41]$. Hence, the generation of a high number of active atomic oxygen species [33-37] could be responsible for the catalytic ozonation of toluene in a new kind of advanced oxidation process.

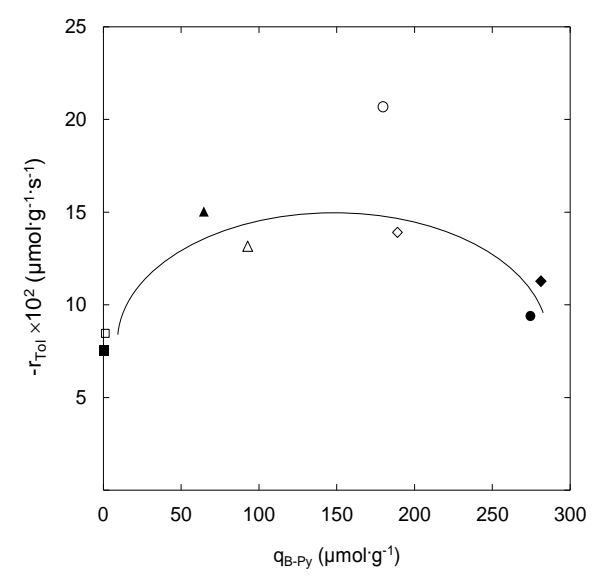

Figure 4. Influence of strong Brønsted acid sites on the toluene ozonation reaction rate. Filled markers represent zeolite samples out-gassed at $623 \mathrm{~K}$ and open markers stand for samples out-gassed at $823 \mathrm{~K}$ : $(\boldsymbol{\square} / \square) \mathrm{NZ} ;(\boldsymbol{\Delta} / \Delta) \mathrm{ZH} 2.4 ;(\diamond / \diamond) \mathrm{NH} 4 \mathrm{Z1} ;(\bullet / \bigcirc)$ 2NH4Z1. Experimental conditions were as follows: $m_{\text {sample }}=150 \mathrm{mg} ; 101 \mathrm{kPa}, 293 \mathrm{~K} ; C_{\text {Tin }}=42.3 \mu \mathrm{mol} \cdot \mathrm{cm}^{-3} ; C_{\text {O3in }}=3.57 \mu \mathrm{mol} \cdot \mathrm{dm}^{-3}$.

\section{Materials and Methods}

\subsection{Materials}

Chilean natural zeolite (NZ) (53\% Clinoptilolite, 40\% Mordenite and 7\% Quartz) was used in this study as a parent material. Its main characteristics have been previously reported $[25,29]$. Three chemically modified samples (ZH2.4, NH4Z1, and 2NH4Z1) were obtained from an NZ sample by two different treatments (acid treatment and ammonium ion-exchange).

Acid treatment was carried out in a Soxhlet extraction apparatus over $6 \mathrm{~h}$ with hydrochloric acid $\left(2.4 \mathrm{~mol} \cdot \mathrm{dm}^{-3}\right)$, using a mass:volume ratio of $0.3 \mathrm{~g}$ of zeolite per $\mathrm{cm}^{3}$ of acid solution, as indicated elsewhere [42]. A rinsing procedure with ultra-pure water was conducted for $3 \mathrm{~h}$ in order to remove any traces of chemical residue on the modified sample (ZH2.4).

Natural zeolite was modified by ion-exchange with ammonium sulfate $\left(0.1 \mathrm{~mol} \cdot \mathrm{dm}^{-3}\right)$, using a solution/solid ratio of 10:1 in a temperature-controlled water bath at $363 \mathrm{~K}$ for $3 \mathrm{~h}$. Then, zeolites samples were rinsed with ultra-pure water for $4 \mathrm{~h}$, replacing the water at 2 and $3 \mathrm{~h}$. The sample obtained here was named as NH4Z1. Another modified zeolite sample (2NH4Z1) was obtained from NH4Z1, applying the same aforementioned ion-exchange procedure.

All zeolite samples were oven-dried at $378 \mathrm{~K}$ for $24 \mathrm{~h}$ and stored in a desiccator until further use. Ultra-pure water was used in all treatments. Ultra-pure water was produced by an EASY pure RF II system (Thermo Fisher Scientific, Marietta, OH, USA). 
Ozone was generated from dry air (analytical grade) using an AZCOZON ozone generator (AZCO Industries Limited Langley, BC, Canada). A toluene stream was produced in situ by bubbling argon in a closed glass flask containing liquid toluene, which was then immersed in a temperature-controlled bath at $261 \mathrm{~K}$. Both procedures are explained in detail in another publication [25].

\subsection{FTIR Spectroscopy Characterisation of Zeolite Acidic Sites by Pyridine Adsorption-Desorption}

The nature of acidic surface sites was identified by FTIR analysis using pyridine as a probe molecule (Py-FTIR) [43]. Zeolite samples were ground into powder prior to wafer formation. The wafer $(d=13 \mathrm{~mm})$ was placed inside the FTIR cell holder and out-gassed under vacuum at $623 \mathrm{~K}$ or $773 \mathrm{~K}$ for $2 \mathrm{~h}$. Then, samples were saturated with pyridine at $293 \mathrm{~K}$ for $24 \mathrm{~h}$. After that, vacuum at $423 \mathrm{~K}$ was applied in order to eliminate the non-adsorbed pyridine. Spectra were collected using a Nicolet Magna-IR 550 spectrometer (Thermo Fisher Scientific, Waltham, MA, USA), following a previously reported procedure [44]. All spectra were processed using OMNIC 5.0 software (Thermo Fisher Scientific, Waltham, MA, USA).

A progressive thermal desorption procedure was conducted (up to $773 \mathrm{~K}$ ) in order to evaluate the strength of Brønsted and Lewis acid sites. Pyridine-saturated zeolite samples were subjected to vacuum at $423,523,623,723$, and $773 \mathrm{~K}$. After heating to the desired temperature, samples were cooled down to $293 \mathrm{~K}$ to register the corresponding spectrum.

The Py-FTIR technique allows quantifying Brønsted and Lewis acid sites, following the aforementioned procedure [45-47]. The surface concentration $\left(q_{\mathrm{s}-\mathrm{Py}}\right)$ of the Brønsted (B-Py $)$ and Lewis (L-Py) acid sites was calculated from the integration of IR bands centred at 1545 and $1450 \mathrm{~cm}^{-1}$, respectively, using Equation (3) [45,48-51]. The values of the molar extinction coefficients used for these bands were 1.13 and $1.28 \mathrm{~cm} \cdot \mu \mathrm{mol}^{-1}$, respectively [43,51].

$$
q_{\mathrm{s}-\mathrm{Py}}=\frac{I A(B, L) \cdot \pi \cdot r_{\mathrm{d}}^{2}}{\xi_{\mathrm{m}} \cdot m_{\mathrm{s}}} \times 1000
$$

where:

$q_{\mathrm{s}-\mathrm{Py}}$ : surface concentration of acid sites (Brønsted or Lewis) $\left(\mu \mathrm{mol} \cdot \mathrm{g}^{-1}\right)$,

$I A(B, L)$ : integrated absorbance of $\mathrm{B}$ or $\mathrm{L}$ band $\left(\mathrm{cm}^{-1}\right)$,

$r_{\mathrm{d}}$ : wafer radius $(\mathrm{cm})$,

$\xi_{\mathrm{m}}$ : pyridine molar extinction coefficient $\left(\mathrm{cm} \cdot \mu \mathrm{mol}^{-1}\right)$,

$m_{\mathrm{s}}$ : wafer mass (mg).

\subsection{Catalytic Ozonation Procedure}

Catalytic ozonation experiments were conducted in a cylindrical " $U$ "-type differential plug flow reactor. In a typical experiment, the reactor was charged with $150 \mathrm{mg}$ of zeolite (natural or chemically modified zeolite), used here as a catalyst (see Figure 5). Then, the zeolite sample was out-gassed under argon flow $\left(100 \mathrm{~cm}^{3} \cdot \mathrm{min}^{-1}\right)$ at $623 \mathrm{~K}$ (or $823 \mathrm{~K}$ ) for $2 \mathrm{~h}$, prior to catalytic ozonation experiments. After that, the sample was cooled down until reaching $293 \mathrm{~K}$ under argon flow. Catalytic ozonation experiments were conducted at $293 \mathrm{~K}$, with an inlet concentration of toluene $\left(42.3 \mu \mathrm{mol} \cdot \mathrm{cm}^{-3}\right)$ and ozone $\left(3.57 \mu \mathrm{mol} \cdot \mathrm{dm}^{-3}\right)$ in a gaseous stream of $100 \mathrm{~cm}^{-3} \cdot \mathrm{min}^{-1}$. Inlet and outlet concentrations of ozone and toluene were registered using a BMT 964 ozone analyser (BMT Messtechnik GmbH, Stahnsdorf, Germany) and a Perkin Elmer Clarus 500 chromatograph (Perkin Elmer, Waltham, MA, USA), respectively. More detailed information about analytic methods are given elsewhere [25]. 


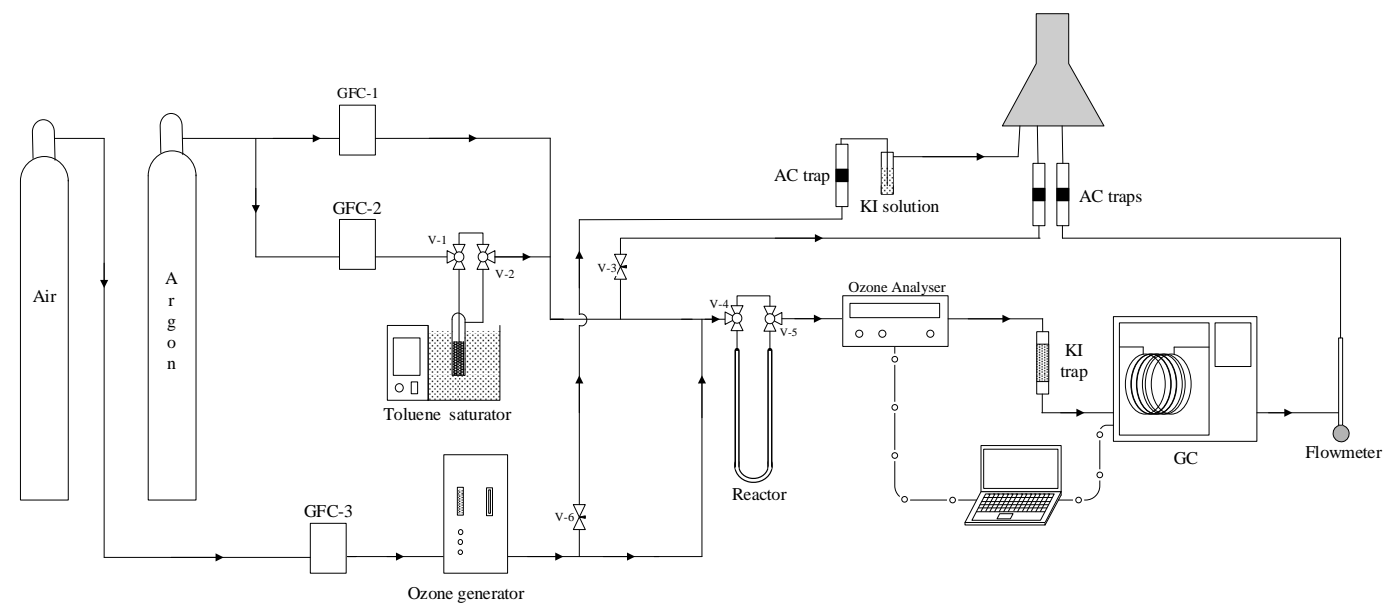

Figure 5. Experimental system of the catalytic ozonation of toluene using natural and modified zeolites.

\section{Conclusions}

The key role of acidic sites of natural and modified zeolite samples on the catalytic ozonation of toluene was confirmed in this study. Toluene oxidation increased when ammonium-exchanged zeolites were used. These samples registered a high density of Lewis acid sites due to the incorporation of new sites as result of the ion-exchange and thermal treatment at $823 \mathrm{~K}$. Results show that strong Lewis acid sites in the 2NH4Z1 sample allowed the achievement of the highest toluene removal.

The incorporation of new Brønsted acid sites on the surface of modified zeolite samples by ion-exchange did not have a direct effect on the reaction rate between toluene and ozone under the experimental conditions studied here. There was only a small increase in the ZH2.4 sample, which could be attributed to the larger surface area of this sample.

The widespread availability of natural zeolite, its low cost, and the feasibility of reproducing the conditions of zeolite modification treatments conducted in this study make natural zeolite a potential catalyst to be applied in a new type of heterogeneous catalytic ozonation process for VOCs control.

Author Contributions: S.A.-M., H.V., M.-H.M. and C.A.Z. conceived and designed the experiments; S.A.-M. performed the experiments; S.A.-M. and H.V. analysed the data; H.V., C.A.Z. and M.-H.M. contributed with reagents/materials/analysis tools; S.A.-M. and H.V. wrote the article.

Acknowledgments: The authors would like to thank the support given by CONICYT, FONDECYT/Regular (Grant No. 1130560); ECOS/CONICYT Program (Grant No. C11E08); BASAL Program (Grant PFB-27); and ANR (Grant No. ANR-10-ECOT-011-01). Serguei Alejandro-Martín would like to extend thanks for the support of the French Embassy in Santiago de Chile for a Doctoral Mobility Scholarship and acknowledges Nicolas Brodu for his valuable help during a research stay at Laboratoire de Génie Chimique, INPT, UPS Université de Toulouse, France. Héctor Valdés gratefully acknowledges funding under CNRS Délégation Midi-Pyrénées contract 618035.

Conflicts of Interest: The authors declare no conflict of interest. The founding sponsors had no role in the design of the study; in the collection, analyses, or interpretation of data; in the writing of the manuscript, and in the decision to publish the results.

\section{References}

1. Gironi, F.; Piemonte, V. VOCs removal from dilute vapour streams by adsorption onto activated carbon. Chem. Eng. J. 2011, 172, 671-677. [CrossRef]

2. Gallego, E.; Roca, F.J.; Perales, J.F.; Guardino, X. Experimental evaluation of VOC removal efficiency of a coconut shell activated carbon filter for indoor air quality enhancement. Build. Environ. 2013, 67, 14-25. [CrossRef]

3. Zhang, X.; Gao, B.; Zheng, Y.; Hu, X.; Creamer, A.E.; Annable, M.D.; Li, Y. Biochar for volatile organic compound (VOC) removal: Sorption performance and governing mechanisms. Bioresour. Technol. 2017, 245, 606-614. [CrossRef] [PubMed] 
4. Pak, S.-H.; Jeon, M.-J.; Jeon, Y.-W. Study of sulfuric acid treatment of activated carbon used to enhance mixed VOC removal. Int. Biodeterior. Biodegradat. 2016, 113, 195-200. [CrossRef]

5. Valdés, H.; Sánchez-Polo, M.; Rivera-Utrilla, J.; Zaror, C.A. Effect of ozone treatment on surface properties of activated carbon. Langmuir 2002, 18, 2111-2116. [CrossRef]

6. Qu, F.; Zhu, L.Z.; Yang, K. Adsorption behaviors of volatile organic compounds (VOCs) on porous clay heterostructures (PCH). J. Hazard. Mater. 2009, 170, 7-12. [CrossRef] [PubMed]

7. Monneyron, P.; Manero, M.H.; Mathé, S. A combined selective adsorption and ozonation process for VOCs removal from air. Can. J. Chem. Eng. 2007, 85, 326-332. [CrossRef]

8. Brodu, N.; Zaitan, H.; Manero, M.-H.; Pic, J.-S. Removal of volatile organic compounds by heterogeneous ozonation on microporous synthetic alumina silicate. Water Sci. Technol. 2012, 66, 2020-2026. [CrossRef] [PubMed]

9. Einaga, H.; Futamura, S. Catalytic oxidation of benzene with ozone over Mn ion-exchanged zeolites. Catal. Commun. 2007, 8, 557-560. [CrossRef]

10. Kwong, C.W.; Chao, C.Y.H.; Hui, K.S.; Wan, M.P. Catalytic ozonation of toluene using zeolite and MCM-41 materials. Environ. Sci. Technol. 2008, 42, 8504-8509. [CrossRef] [PubMed]

11. Chao, C.Y.H.; Kwong, C.W.; Hui, K.S. Potential use of a combined ozone and zeolite system for gaseous toluene elimination. J. Hazard. Mater. 2007, 143, 118-127. [CrossRef] [PubMed]

12. Kwong, C.W.; Chao, C.Y.H.; Hui, K.S.; Wan, M.P. Removal of VOCs from indoor environment by ozonation over different porous materials. Atmos. Environ. 2008, 42, 2300-2311. [CrossRef]

13. Yosefi, L.; Haghighi, M.; Allahyari, S.; Shokrani, R.; Ashkriz, S. Abatement of toluene from polluted air over $\mathrm{Mn} / \mathrm{Clinoptilolite-} \mathrm{CeO}_{2}$ nanopowder: Impregnation vs. Ultrasound assisted synthesis with various Mn-loading. Adv. Powder Technol. 2015, 26, 602-611. [CrossRef]

14. Ahmadi, M.; Haghighi, M.; Kahforoushan, D. Influence of active phase composition (Mn, $\mathrm{Ni}, \mathrm{Mn}_{x} \mathrm{Ni}_{10-x}$ ) on catalytic properties and performance of clinoptilolite supported nanocatalysts synthesized using ultrasound energy toward abatement of toluene from polluted air. Process Saf. Environ. Protect. 2017, 106, 294-308. [CrossRef]

15. Rafatullah, M.; Sulaiman, O.; Hashim, R.; Ahmad, A. Adsorption of methylene blue on low-cost adsorbents: A review. J. Hazard. Mater. 2010, 177, 70-80. [CrossRef] [PubMed]

16. Allen, S.J.; Ivanova, E.; Koumanova, B. Adsorption of sulfur dioxide on chemically modified natural clinoptilolite. Acid modification. Chem. Eng. J. 2009, 152, 389-395. [CrossRef]

17. Valdés, H.; Solar, V.A.; Cabrera, E.H.; Veloso, A.F.; Zaror, C.A. Control of released volatile organic compounds from industrial facilities using natural and acid-treated mordenites: The role of acidic surface sites on the adsorption mechanism. Chem. Eng. J. 2014, 244, 117-127. [CrossRef]

18. Kuleyin, A. Removal of phenol and 4-chlorophenol by surfactant-modified natural zeolite. J. Hazard. Mater. 2007, 144, 307-315. [CrossRef] [PubMed]

19. Alejandro, S.; Valdés, H.; Manéro, M.-H.; Zaror, C.A. Oxidative regeneration of toluene-saturated natural zeolite by gaseous ozone: The influence of zeolite chemical surface characteristics. J. Hazard. Mater. 2014, 274, 212-220. [CrossRef] [PubMed]

20. Soylu, G.S.P.; Özçelik, Z.; Boz, I. Total oxidation of toluene over metal oxides supported on a natural clinoptilolite-type zeolite. Chem. Eng. J. 2010, 162, 380-387. [CrossRef]

21. Amereh, M.; Haghighi, M.; Estifaee, P. The potential use of $\mathrm{HNO}_{3}$-treated clinoptilolite in the preparation of $\mathrm{Pt} / \mathrm{CeO}_{2}$-clinoptilolite nanostructured catalyst used in toluene abatement from waste gas stream at low temperature. Arab. J. Chem. 2018, 11, 81-90. [CrossRef]

22. Gregg, S.J.; Sing, K.S.W. Adsortion, Surface Area and Porosity; Academic Press: London, UK, 1982; p. 371.

23. Englert, A.H.; Rubio, J. Characterization and environmental application of a chilean natural zeolite. Int. J. Miner. Process. 2005, 75, 21-29. [CrossRef]

24. Christidis, G.E.; Moraetis, D.; Keheyan, E.; Akhalbedashvili, L.; Kekelidze, N.; Gevorkyan, R.; Yeritsyan, H.; Sargsyan, H. Chemical and thermal modification of natural HEU-type zeolitic materials from armenia, georgia and greece. Appl. Clay Sci. 2003, 24, 79-91. [CrossRef] 
25. Alejandro, S.; Valdés, H.; Manero, M.H.; Zaror, C.A. BTX abatement using chilean natural zeolite: The role of bronsted acid sites. Water Sci. Technol. 2012, 66, 1759-1769. [CrossRef] [PubMed]

26. Valdés, H.; Alejandro, S.; Zaror, C.A. Natural zeolite reactivity towards ozone: The role of compensating cations. J. Hazard. Mater. 2012, 227-228, 34-40. [CrossRef] [PubMed]

27. Barrer, R.M. Molecular sieve sorbents from clinoptilolite. Can. J. Chem. 1964, 42, 1480-1487. [CrossRef]

28. Valdés, H.; Farfán, V.J.; Manoli, J.A.; Zaror, C.A. Catalytic ozone aqueous decomposition promoted by natural zeolite and volcanic sand. J. Hazard. Mater. 2009, 165, 915-922. [CrossRef] [PubMed]

29. Alejandro, S.; Valdés, H.; Zaror, C.A. Natural zeolite reactivity towards ozone: The role of acid surface sites. J. Adv. Oxidat. Technol. 2011, 14, 182-189. [CrossRef]

30. Stöcker, M. Gas phase catalysis by zeolites. Micropor. Mesopor. Mater. 2005, 82, 257-292. [CrossRef]

31. Guillemot, M.; Mijoin, J.; Mignard, S.; Magnoux, P. Volatile organic compounds (VOCs) removal over dual functional adsorbent/catalyst system. Appl. Catal. B Environ. 2007, 75, 249-255. [CrossRef]

32. Vannice, M.A. Kinetics of Catalytic Reactions; Springer Science \& Business Media, Inc.: New York, NY, USA, 2005; pp. 77-78, 170-171.

33. Kasprzyk-Hordern, B.; Ziólek, M.; Nawrocki, J. Catalytic ozonation and methods of enhancing molecular ozone reactions in water treatment. Appl. Catal. B Environ. 2003, 46, 639-669. [CrossRef]

34. Bulanin, K.M.; Lavalley, J.C.; Tsyganenko, A.A. IR spectra of adsorbed ozone. Colloids Surf. A Physicochem. Eng. Aspects 1995, 101, 153-158. [CrossRef]

35. Li, W.; Oyama, S.T. Mechanism of ozone decomposition on a manganese oxide catalyst. 2. Steady-state and transient kinetic studies. J. Am. Chem. Soc. 1998, 120, 9047-9052. [CrossRef]

36. Rezaei, E.; Soltan, J. Low temperature oxidation of toluene by ozone over $\mathrm{MnO}_{x} /$ alumina and $\mathrm{MnO}_{x} / \mathrm{MCM}-41$ catalysts. Chem. Eng. J. 2012, 198-199, 482-490. [CrossRef]

37. Bulanin, K.M.; Lavalley, J.C.; Tsyganenko, A.A. Infrared study of ozone adsorption on CaO. J. Phys. Chem. B 1997, 101, 2917-2922. [CrossRef]

38. Roque-Malherbe, R. Complementary approach to the volume filling theory of adsorption in zeolites. Micropor. Mesopor. Mater. 2000, 41, 227-240. [CrossRef]

39. Roque-Malherbe, R.; Ivanov, V. Codiffusion and counterdiffusion of para-xylene and ortho-xylene in a zeolite with $10 \mathrm{MR} / 12 \mathrm{MR}$ interconnected channels. An example of molecular traffic control. J. Mol. Catal. A Chem. 2009, 313, 7-13. [CrossRef]

40. Einaga, H.; Futamura, S. Catalytic oxidation of benzene with ozone over alumina-supported manganese oxides. J. Catal. 2004, 227, 304-312. [CrossRef]

41. Einaga, H.; Ogata, A. Benzene oxidation with ozone over supported manganese oxide catalysts: Effect of catalyst support and reaction conditions. J. Hazard. Mater. 2009, 164, 1236-1241. [CrossRef] [PubMed]

42. Valdés, H.; Tardón, R.F.; Zaror, C.A. Role of surface hydroxyl groups of acid-treated natural zeolite on the heterogeneous catalytic ozonation of methylene blue contaminated waters. Chem. Eng. J. 2012, 211-212, 388-395. [CrossRef]

43. Guisnet, M.; Ayrault, P.; Coutanceau, C.; Fernanda Alvarez, M.; Datka, J. Acid properties of dealuminated beta zeolites studied by IR spectroscopy. J. Chem. Soc. Faraday Trans. 1997, 93, 1661-1665. [CrossRef]

44. Simon-Masseron, A.; Marques, J.P.; Lopes, J.M.; Ribeiro, F.R.; Gener, I.; Guisnet, M. Influence of the Si/Al ratio and crystal size on the acidity and activity of HBEA zeolites. Appl. Catal. A Gen. 2007, 316, 75-82. [CrossRef]

45. Reddy, C.R.; Bhat, Y.S.; Nagendrappa, G.; Jai Prakash, B.S. Brønsted and Lewis acidity of modified montmorillonite clay catalysts determined by FT-IR spectroscopy. Catal. Today 2009, 141, 157-160. [CrossRef]

46. Jin, F.; Li, Y. A FTIR and TPD examination of the distributive properties of acid sites on ZSM-5 zeolite with pyridine as a probe molecule. Catal. Today 2009, 145, 101-107. [CrossRef]

47. Tamura, M.; Shimizu, K.-I.; Satsuma, A. Comprehensive IR study on acid/base properties of metal oxides. Appl. Catal. A Gen. 2012, 433-434, 135-145. [CrossRef]

48. Barzetti, T.; Selli, E.; Moscotti, D.; Forni, L. Pyridine and ammonia as probes for FTIR analysis of solid acid catalysts. J. Chem. Soc. Faraday Trans. 1996, 92, 1401-1407. [CrossRef]

49. Emeis, C.A. Determination of integrated molar extinction coefficients for infrared absorption bands of pyridine adsorbed on solid acid catalysts. J. Catal. 1993, 141, 347-354. [CrossRef] 
50. Collignon, F.; Poncelet, G. Comparative vapor phase synthesis of ETBE from ethanol and isobutene over different acid zeolites. J. Catal. 2001, 202, 68-77. [CrossRef]

51. Konan, K.L.; Peyratout, C.; Smith, A.; Bonnet, J.P.; Magnoux, P.; Ayrault, P. Surface modifications of illite in concentrated lime solutions investigated by pyridine adsorption. J. Colloid Interface Sci. 2012, 382, 17-21. [CrossRef] [PubMed] 